\title{
GLYCOSIDASES IN FOWL SEMEN
}

\author{
YASUYUKI KANNAN \\ Laboratory of Animal Reproduction, Faculty of Agriculture, \\ Kobe University, Kobe 657, Japan
}

(Received 3rd April 1974)

It seems probable that the glycosidases in spermatozoa and seminal plasma are involved in the fertilization process. In mammals, this possibility may be supported by the presence of several glycosidases, hyaluronidase and neuraminidase (Hartree \& Srivastava, 1965; Srivastava, Adams \& Hartree, 1965; Srivastava, Zaneveld \& Williams, 1970; Srivastava, 1973), $\beta$-N-acetylglucosaminidase (Conchie \& Mann, 1957), $\alpha$-mannosidase (Conchie \& Mann, 1957) and $\beta$-glucuronidase (Bernstein \& Teichman, 1973) in sperm acrosomes. Although there is a detailed report by Conchie \& Mann (1957) on glycosidases in mammalian semen, little work has been done on this group of enzymes in fowl semen. The present communication deals with normal activity levels of glycosidases in whole semen and in the spermatozoa of one breed of domestic fowl.

Semen was collected from ten White Leghorn males by the abdominal massage technique (Burrows \& Quinn, 1937). For enzyme assay, aliquots of pooled semen, containing 3.9 to $4.3 \times 10^{9}$ spermatozoa $/ \mathrm{ml}$, were suitably diluted with $0.15 \mathrm{M}-\mathrm{NaCl}$ containing Triton $\mathrm{X}-100$ at a final concentration of $0.1 \%$. Spermatozoa were prepared by washing with Ringer-phosphate medium at pH 7.3 (Brooks \& Mann, 1972) and by diluting the cells with the detergent at the same concentration as above.

At optimal $\mathrm{pH}$, all enzymes were assayed according to the procedures described by Conchie, Findlay \& Levvy (1959) with some modifications. The reaction mixture $(1.0 \mathrm{ml})$ was incubated during a fixed period at $41^{\circ} \mathrm{C}$ and the reaction was stopped by adding $1.0 \mathrm{ml}$ of $0.4 \mathrm{M}$-glycine buffer at $\mathrm{pH} 10.5$. The absorbance of the supernatant fluid obtained by centrifugation was determined spectrophotometrically at $410 \mathrm{~nm}$.

The normal levels of glycosidase activities in the whole semen and spermatozoa of fowl are summarized in Table 1. Among the enzymes present in whole semen, $\beta$-N-acetylglucosaminidase was the most active, with $\alpha$-mannosidase ranking next in activity. This finding is similar to that reported for mammalian semen by Conchie \& Mann (1957). The activities of $\beta$-mannosidase and $\beta$ galactosidase were very low compared to those of the two enzymes mentioned above, while the activity of the remaining enzymes was either weak or almost negligible. The enzymes, $\beta$-N-acetylglucosamindase and $\alpha$-mannosidase, were shown to be present in the spermatozoa themselves.

The activity of $\beta$-N-acetylglucosaminidase in spermatozoa and seminal plasma showed the same optimal $\mathrm{pH}$ of 3.5 . It could be calculated, therefore, 
that about $1 / 10$ of this enzyme activity found in whole fowl semen was derived from the spermatozoa. In rams, the contribution of the spermatozoa to the enzyme activity in whole semen has been reported to be 1/5 (Conchie \& Mann, 1957). This difference may be attributed to the fact that the acrosome of the fowl spermatozoon is minute compared to that of mammals. The relative values for $\alpha$-mannosidase could not be estimated because of the different $\mathrm{pH}$ optima exhibited by the enzymes, that for sperm $\alpha$-mannosidase being at $\mathrm{pH}$ 3.6 and that for the enzyme in the seminal plasma being at $\mathrm{pH} 4.2$.

Table 1. Normal levels of glycosidase activities in the whole semen and spermatozoa of White Leghorn cocks

\begin{tabular}{l|r}
\hline \multicolumn{1}{c|}{ Enzyme } & Mean activity \pm S.D.* \\
\hline Whole semen & \\
$\beta$-N-acetylglucosaminidase & $340.58 \pm 21.93(12)$ \\
$\alpha$-Mannosidase & $244 \cdot 17 \pm 21.69(12)$ \\
$\beta$-Mannosidase & $16.33 \pm 1.75(12)$ \\
$\alpha$-Galactosidase & $0.58 \pm 0.05(5)$ \\
$\beta$-Galactosidase & $14.55 \pm 1.67(11)$ \\
$\alpha$-Glucosidase & $3.49 \pm 0.70(5)$ \\
$\beta$-Glucosidase & $0.36 \pm 0.07(5)$ \\
$\beta$-Glucuronidase & $0.25 \pm 0.04(5)$ \\
Spermatozoa & \\
$\beta$-N-acetylglucosaminidase & $8 \cdot 23 \pm 0.32(12)$ \\
$\alpha$-Mannosidase & $2.65 \pm 0.11(12)$ \\
\hline
\end{tabular}

* Each enzyme activity is expressed as $\mu \mathrm{mol}$ p-nitrophenol liberated per ml of whole semen or per $10^{9}$ spermatozoa in $1 \mathrm{hr}$ at $41^{\circ} \mathrm{C}$. The number of samples examined is given in parentheses.

The author wishes to express gratitude to Professor T. Ishibashi for his review of this manuscript.

\section{REFERENGES}

Bernstein, M. H. \& Teichman, R. J. (1973) A chemical procedure for extraction of the acrosomes of mammalian spermatozoa. F. Reprod. Fert. 33, 239.

BRooks, D. E. \& MANN, T. (1972) Relation between the oxidation state of nicotinamide-adenine dinucleotide and the metabolism of spermatozoa. Biochem. F. 129, 1023.

Burrows, W. H. \& Quin, J. P. (1937) Gollection of spermatozoa from domestic fowl and turkey. Poult. Sci. 16, 19.

Conchie, J., Findlay, J. \& Levvy, G. A. (1959) Mammalian glycosidases. Distribution in the body. Biochem. 7. 71, 318.

Conchie, J. \& MANN, T. (1957) Glycosidases in mammalian sperm and seminal plasma. Nature, Lond. $179,1190$.

Hartree, E. F. \& Srivastava, P. N. (1965) Chemical composition of the acrosomes of ram spermatozoa. 7. Reprod. Fert. 9, 47.

SRIvastava, P. N. (1973) Removal of acrosomes of ram and rabbit spermatozoa. F. Reprod. Fert. 33, 323.

Srivastava, P. N., Adams, G. E. \& Hartree, E. F. (1965) Enzymatic action of acrosomal preparations on the rabbit ovum in vitro. F. Reprod. Fert. 10,61.

Srivastava, P. N., Zaneveld, L. J. D. \& Williams, W. L. (1970) Mammalian sperm acrosomal neuraminidase. Biochem. biophys. Res. Commun. 39, 575. 